\title{
A note from the Editor
}

This issue of the Review is devoted to a topic which might appear academic at first glance but is in fact closely linked to action, namely the dissemination of the fundamental principles and basic rules of international humanitarian law among all those who have to respect the law or ensure that it is respected when conflict breaks out. Admittedly, it is hard to establish with any degree of certainty whether and in what way individual attitudes and behaviour patterns have been changed by dissemination work and to determine whether its goals have been reached. Yet surely it is even more difficult to spread knowledge of the law among those responsible for the spiral of violence in modern conflicts, and especially to do so effectively. Therein lies one of the major challenges facing us today.

At the Review's suggestion, several ICRC staff members have contributed their thoughts on different aspects of the dissemination effort, ranging from the teaching of the humanitarian principles to young people to instruction in the law of war for soldiers. Among the articles published in this issue, two describe dissemination activities carried out in Colombia and in Bosnia-Herzegovina, while a third considers an experiment conducted in Burundi, where the task was to explain the humanitarian principles in terms that could be understood and accepted by the various sectors of the population.

All the contributors to this issue have had extensive experience working as dissemination specialists in the field. The situations they encountered are as diverse as their personal backgrounds: some were trained as teachers, others are legal experts, and others still are former military officers or journalists.

A picture taken some years ago at an ICRC dissemination seminar shows a group of young soldiers gathered around a smiling general who 
later became a notorious tyrant. The soldiers are each holding a booklet on the basic rules of international humanitarian law, its cover emblazoned with a red cross. Should we laugh or cry? Is there any point to dissemination work? - In one of the States that became independent after the collapse of the Soviet Union, two young colonels encountered in an empty office of the future Ministry of Defence told an ICRC representative one day that in their entire military careers they had never even heard of the Geneva Conventions. Yet according to official reports that regularly reached the ICRC before 1991, international humanitarian law formed part of the programme of military instruction. Can we believe the parties to the humanitarian treaties when they pledge "in time of peace as in time of war, to disseminate the text [of these instruments] as widely as possible"?

None of the articles in this issue provides a direct answer to those questions, which may be too obvious and perhaps even simplistic. Instead, these articles offer a critical analysis of the experience acquired so far and explore new methods and approaches that will give the dissemination effort a better chance of achieving its goal. For their authors, all of them seasoned ICRC delegates, have witnessed large-scale tragedy at first hand - the disaster that struck the African Great Lakes region being but the latest in a long series. In the face of the terrible suffering that people inflict on their fellow human beings - often neighbours and sometimes even friends - there is no more room for doubt. Never has there been such a need for dissemination work, and despite the scant means at our disposal we must forge ahead and never waver in our efforts to convince people that one of the things that can be done to save lives and preserve human dignity is to behave in all circumstances with at least a modicum of humanity.

To continue the story of the brief encounter with the two colonels, both promised to do their utmost to ensure that the Geneva Conventions were given their rightful place in the programmes of instruction for their new armed forces. In this connection, it should be mentioned that the ICRC's recently created Advisory Service on International Humanitarian Law ${ }^{\prime}$ has already organized a seminar to advise newly appointed heads of military instruction programmes on the steps to be taken for troops to receive proper training in international humanitarian law.

See Paul Berman, "The ICRC's Advisory Service on International Humanitarian Law: The challenge of national implementation", IRRC, No. 312, May-June 1996. pp. 338-347. 
Dissemination work must not be seen as a panacea, however, nor as a scapegoat. In itself, dissemination is not enough to avert violations of humanitarian law. Despite the considerable efforts made in this respect, crimes are still being - and will probably continue to be - committed in the future. On the other hand, this is not a valid argument for denying dissemination's raison d'être and simply giving up. Activities aimed at spreading knowledge of the law, or, conversely, the lack of dissemination activities, are not the only factor that determines the behaviour of regular armed forces, militias or civilians. In the final analysis, it is not up to disseminators alone to ensure respect for the rules of international humanitarian law. The ultimate responsibility lies with the political authorities, military commanders, all those who have armed men under their control, and - as a last resort - courts of law.

The Review 